\title{
The correlation between RT-PCR and ELISA assay on hepatitis $C$ positive serum samples
}

\author{
Noor Bahadar ${ }^{1 *}$, Fawad $\mathrm{Ali}^{2}$, Muhammad Israr $^{3}$ and Shabeer Ahmad ${ }^{4}$ \\ 1. School of Life Sciences, Northeast Normal University Changchun, Jilin PR, China \\ 2. ICS, University of Peshawar, Peshawar, KP, Pakistan \\ 3. Department of Biochemistry, Faculty of Life Sciences, Bacha Khan University, Charsadda, Pakistan \\ 4. Department of Microbiology, Abasyn University Peshawar, Pakistan \\ *Corresponding author's email: noorizever@yahoo.com \\ Citation \\ Noor Bahadar, Fawad Ali, Muhammad Israr and Shabeer Ahmad. The correlation between RT-PCR and ELISA \\ assay on hepatitis C positive serum samples. Pure and Applied Biology. Vol. 5, Issue 4, pp689-694. \\ http://dx.doi.org/10.19045/bspab.2016.50087
}

Received: 21/03/2016 Revised: 28/062016

Accepted: 04/07/2016

Online First: 09/07/2016

\section{Abstract}

Hepatitis C Virus is an infectious entity mainly affects liver. The HCV belongs to family Flaviviridae of viruses. The virion has single stranded positive polarity RNA genome. It was identified in 1989. It is transmitted through transfusion of infected blood, homosexuality, vertical transmission, inadequately sterilized surgical or dental instruments. Different techniques for diagnosis of HCV are available like ICT, ELISA, MEIA and RT-PCR etc. The objective of this study was to find out the most sensitive and reliable method for diagnosis of HCV infection. The study was conducted at a Public Sector Hospital, Hayat Abad Medical Complex Hayat Abad, Peshawar. A total of 300 samples tested for anti HCV antibodies on ELISA, out of which 14 $(4.66 \%)$ were found positive to anti-HCV antibodies. These positive cases were considered for HCV genome detection using RT-PCR. The results showed that 05 (1.66\%) samples are positive for HCV RNA while 09 were found negative. It is determined that RT-PCR technique can be used for the detection of Hepatitis $\mathrm{C}$ Virus because it is quick and reliable.

Keywords: Hepatitis C virus; OD value; Ct cycle; False positive; Correlation

\section{Introduction}

Hepatitis $\mathrm{C}$ is an infectious viral disease of liver. The infection is caused by Hepatitis $\mathrm{C}$ virus. $\mathrm{HCV}$ belongs to Flaviviridae family of viruses, compressed of about $9.6 \mathrm{~kb}$ single stranded positive sense RNA genome [1]. Based on genotypes, six major $\mathrm{HCV}$ strains and more than fifty subtypes have been identified so far [2]. The disease is often asymptomatic initially, however, infection with HCV can lead to chronic liver disease in which scarring of liver can occur and if it continues to progress then cirrhosis and in some cases hepatocellular carcinoma is the end result that appears after years [3]. The HCV infection is not confined to a limited area, the prevalence is all over the world, rising health, economic and social issues [3, 4]. The prevalence is directly proportional to the developed and developing regions as the developed countries has proper hygiene and better protection measures as compared to developing regions. The overall prevalence 
of hepatitis $\mathrm{C}$ infection contamination in the world is evaluated by the World Health Organization to be around 3\%. This corresponds to about 170 million persons are infected throughout the globe. According to WHO recent reports, three to four million new cases diagnosed and more than 0.25 million deaths each year [5]. United States $[5,6]$, Western and Northern Europe [7, 8], Japan [9], and Australia [10] has reduced the prevalence rate during past two decades. This decline is based on the awareness, improved safety of blood products, affordable and effective therapies.

African and Mediterranean areas are at the high risk of HCV [11]. The highest prevalence has been reported in Egypt, the highest of all over the world [12, 13]. Mongolia has been reported the highest prevalence country of HCV in Asia, second is Uzbekistan and next is Pakistan [13]. In Pakistan, approximately 10 million cases have been reported [14].

The virus is a blood borne pathogen. Previous studies of clinical cases have identified the transfusion of blood products as major factor in the transmission of hepatitis $\mathrm{C}$ infection. The transmission modes of $\mathrm{HCV}$ are multiple use of medical equipment, transfusion of unscreened blood or blood products, shaving razors, sharing of toothbrushes, vertical and sexual transmission [15]. IDUs (Injection Drugs Users), homosexuality are nowadays on the rise in Pakistan although recently they contribute minimally to the huge burden of the disease [16].

To proper document viremia in a patient the clinicians usually approaches to test initially immunochromatography (ICT) or antibodies for $\mathrm{HCV}$ (anti-HCV) followed by RNA detection [17]. Thus the diagnoses of the $\mathrm{HCV}$ can be classified into molecular and serological diagnosis. The molecular diagnosis can be grouped into qualitative and quantitative. The serological test results like ELISA, RIBA, EIA etc can be confirmed with quantitatively by polymerase chain reaction (PCR). The PCR is also useful to document the efficacy of antiviral therapy [18, 19]. The minute amounts of nucleic acids can be quantified precisely by using Real-time PCR. The PCR amplification products detection is allowed at the early stage of reaction, which is an advantage of Real-time PCR over the traditional PCR which based post PCR detection like agarose gels electrophoresis to detection the product of PCR at the end of reaction. Moreover, RT-PCR is more reliable [20]. Nucleic acid (DNA/RNA) can be easily detected and quantified with more precision using Real Time PCR rather than traditional techniques [21].

The detection of HCV RNA in a serum sample can confirm the infection. Moreover, when HCV infection is assumed to have occurred immediately prior to the examination, detection of the nucleic acid can significantly shorten the window phase [22]. Real Time Polymerase Chain Reaction (RT-PCR) is the most sensitive method for the detection and quantitation of RNA, especially for low copy number [23, 24]. In the current study we utilized two diagnostic techniques for the detection of $\mathrm{HCV}$ in blood serum. The ELSIA which is antibodies based identification followed by the Nucleic Acid Based identification, Real Time PCR.

\section{Materials and methods}

The study was conducted at the department of pathology, Hayat Abad Medical Complex Hayat Abad, Peshawar during March to June 2015. The purpose of the entire study was to identify the correlation between the serological and nucleic acid base diagnosis of HCV. The informed consent was obtained from the patients before sample collection. 


\section{Laboratory methods \\ ELISA}

A total of 300 blood samples were screened for the presence of Anti-HCV antibodies through third generation ELISA [Biokit, Barcelona SA, Spain]. Serum was separated from $5 \mathrm{ml}$ of blood in the disposable tubes. Further process were followed according to the manufacturers instructions ELISA (Biokit, Barcelona SA, Spain).

Real Time PCR and Extraction of RNA

The anti HCV positive cases were further processed for the detection of RNA using Sacace (Sacace, Biotechnology, Italy) extraction and RT-PCR kit. Cepheid smart cycler (Nasdaq: CPHD, California, US) was used for the amplification process.

Table 1. Total number of Hepatitis $\mathrm{C}$ positive cases and its percentage

\begin{tabular}{|l|l|l|l|}
\hline Total no. of samples & Positive & $\begin{array}{l}\text { Percentage of } \\
\text { Positive }\end{array}$ & $\begin{array}{l}\text { Negative on } \\
\text { PCR }\end{array}$ \\
\hline 300 & 14 & 4.66 & 268 \\
\hline
\end{tabular}

Table 2. Results obtained by RT- PCR

\begin{tabular}{|l|l|l|l|}
\hline Total no. of samples & Positive on PCR & $\begin{array}{l}\text { Percentage of } \\
\text { Positive }\end{array}$ & $\begin{array}{l}\text { Negative on } \\
\text { PCR }\end{array}$ \\
\hline 14 & 05 & 1.66 & 09 \\
\hline
\end{tabular}

The deficiency of virus isolation procedures and antigen detection methods has made nucleic acid-based amplification the best method for the direct detection of HCV Rys, P., N. et al [25]. Indeed, through PCR it is conceivable to judge the status of the infection, to detect viral replication in seropositive patients, and to diagnose the infection in immunocompromised patients and during the window phase that precedes seroconversion Victor, $\mathrm{T}$. et al [26]. In the current study we found that $4.66 \%$ cases were positive to anti $\mathrm{HCV}$ antibodies and $1.66 \%$ were positive for $\mathrm{HCV}$ RNA. Our

\section{Results and discussion}

Three hundred blood samples were screened for the presence of anti HCV antibodies. These samples were collected from the patients who have visited the hospital purposely. Out of 300 blood samples 14 (4.66\%) were found positive for Hepatitis C Virus antibodies on ELISA. The positivity of the cases was considered according to the defined OD value. The positive cases to anti $\mathrm{HCV}$ antibodies, were further analyzed for the presence of RNA. Among these 14, 09 cases were found negative for HCV RNA, while $05(1.66 \%)$ cases were found active to the infection (Table 2). 


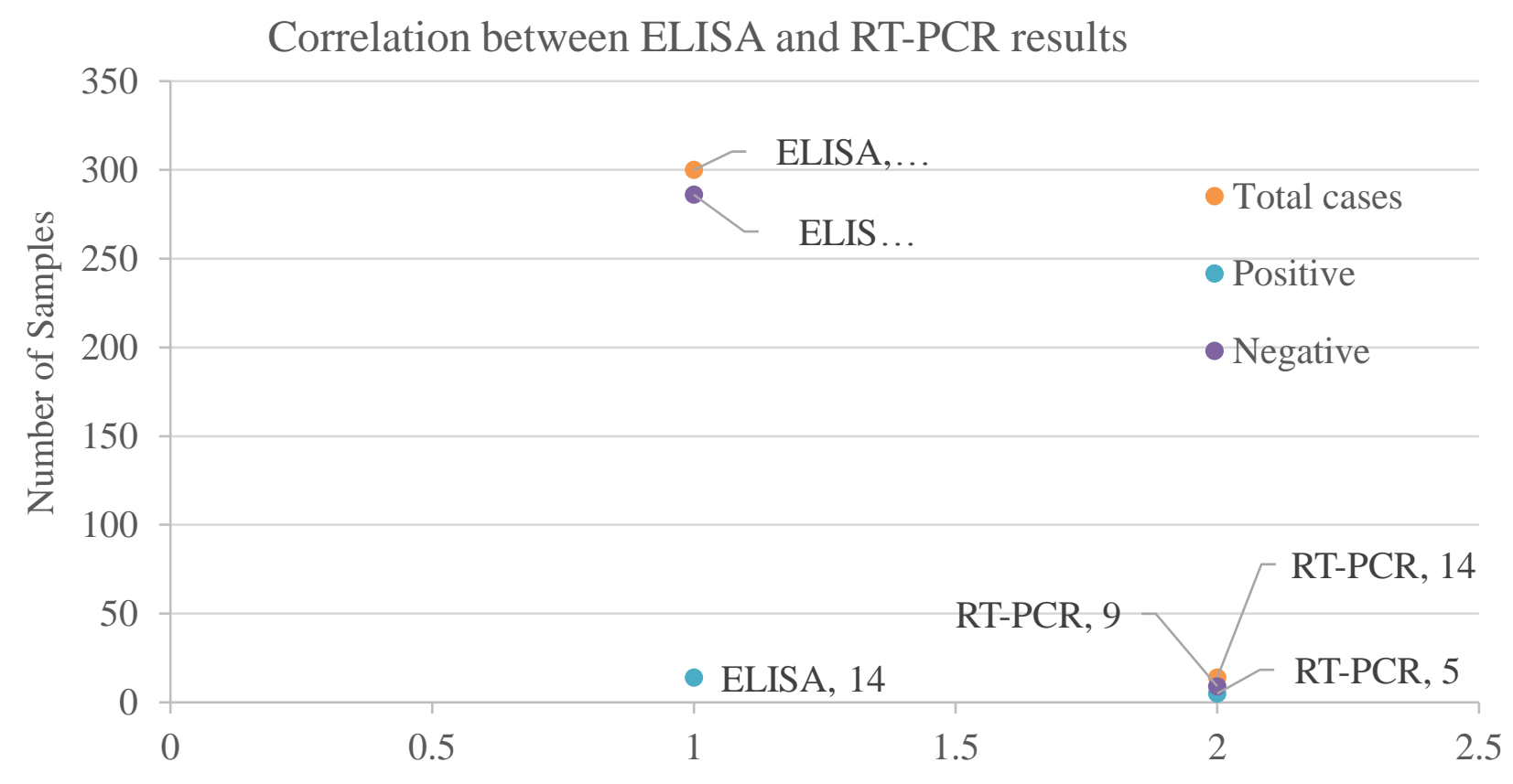

Figure 1. Correlation between ELISA and RT-PCR results

\section{Conclusion and recommendations}

The study has provided us knowledge of the importance of diagnosis of the disease prior to therapy. The following points should be taken into consideration.

Initial diagnosis may be carried serologically but the positive cases must be confirmed with nucleic acid based technique.

The persons with Hepatitis symptoms should be tested for infection.

The immunocompromised patients having liver diseases should be tested for infection.

\section{Authors' contributions}

Conceived and designed the experiments: $\mathrm{N}$ Bahadar \& S Ahmad, Performed the experiments: $\mathrm{N}$ Bahdar, M Israr \& $\mathrm{F}$ Khan, Analyzed the data: F Khan \& M Israr, Wrote the paper: $\mathrm{N}$ Bahadar

\section{Acknowledgment}

The authors are thankful to Mr. Noor Rehman for his unconditionl guidance. We are also thankful to Mr. Naveed and Mr. Izhar Ullah for providing the proper guidance in the laboratory during the work.

\section{References}

1. Moradpour D, Penin F \& Rice CM (2007). Replication of hepatitis C virus. Nat Rev Microbiol. 5: 453-463.

2. Ali A, Ahmed H \& Idrees M (2010). Molecular epidemiology of Hepatitis C virus genotypes in Khyber Pakhtoonkhaw of Pakistan. Virology Journal. 7:203.

3. Lavanchy D (2011). Evolving epidemiology of hepatitis C virus. Clin Microbiol Infect. 17: 107-115.

4. Hajarizadeh B, Grebely J, Dore GJ (2013). Epidemiology and natural history of HCV infection. Nat Rev Gastroenterol Hepatol. 10: 553-562.

5. Armstrong GL, Wasley A, Simard EP, McQuillan GM, Kuhnert WL \& Alter MJ (2006). The prevalence of hepatitis C virus infection in the United States, 1999 through 2002. Ann Intern Med. 144: 705714.

6. Williams IT, Bell BP, Kuhnert W \& Alter MJ (2011). Incidence and transmission patterns of acute hepatitis $\mathrm{C}$ in the United 
States, 1982-2006. Arch Intern Med. 171: 242-248.

7. Duberg A, Janzon R, Bäck E, Ekdahl K \& Blaxhult A (2008). The epidemiology of hepatitis C virus infection in Sweden. Euro Surveill 13: 18882.

8. Delarocque-Astagneau E, Meffre C, Dubois F, Pioche C, Le Strat Y, RoudotThoraval F, Hillon P, Silvain C, Dhumeaux D \& Desenclos JC (2010). The impact of the prevention programme of hepatitis $\mathrm{C}$ over more than a decade: the French experience. J Viral Hepat. 17: 435443.

9. Chung H, Ueda T \& Kudo M (2010). Changing trends in hepatitis $\mathrm{C}$ infection over the past 50 years in Japan. Intervirology. 53: 39-43.

10. Razali K, Thein HH, Bell J, CooperStanbury M, Dolan K, Dore G, George J, Kaldor J, Karvelas M, Li J, Maher L, McGregor S, Hellard M, Poeder F, Quaine J, Stewart K, Tyrrell H, Weltman M, Westcott O, Wodak A \& Law M (2007). Modelling the hepatitis $\mathrm{C}$ virus epidemic in Australia. Drug Alcohol Depend. 91: 228-235.

11. Lavanchy D (2009). The global burden of hepatitis C. Liver Int 29 Suppl. 1: 74-81.

12. Guerra J, Garenne M, Mohamed MK \& Fontanet A (2012). HCV burden of infection in Egypt: results from a nationwide survey. J Viral Hepat. 19: 560567.

13. Qureshi H, Bile KM, Jooma R, Alam SE $\&$ Afridi HU (2010). Prevalence of hepatitis $\mathrm{B}$ and $\mathrm{C}$ viral infections in Pakistan: findings of a national survey appealing for effective prevention and control measures. East Mediterr Health J 16: S15-S23.

14. Hamid S, Umar M, Alam A, Siddiqui A, Qureshi H \& Butt J (2004). Pakistan Society of Gastroenterology. PSG consensus statement on management of hepatitis C Virus infection. J Pak Med Assoc. 54: 46-50.

15. Aslam M \& Aslam J (2001). Seroprevalence of the antibody to hepatitis $\mathrm{C}$ in selected groups in The Punjab region of Pakistan. J Clin Gast 33:407-11.

16. Liz Highleyman (2002). Preventing HCV Transmission in personal care settings HCSP Ver. $\quad 1.0 \quad$ (http://usedtransmissions.com/Preventing_HCV_Tran smission.pdf accessed June 29, 2016).

17. Strader D, Teresa W, Thomas D \& Seeff LB (2004). Diagnosis, Management, and Treatment of Hepatitis C. Journal of Hepatology. 37(4): 1147-1171.

18. Jungkind D (2001). Molecular testing for infectious disease. Science 294: 15531555.

19. Pawlotsky M (2002). Use and interpretation of virological tests for hepatitis C. Journal of Hepatology. 36: 6573.

20. Bar T, Stahlberg A, Muszta A \& Kubista M (2003). Kinetic Outlier Detection (KOD) in real-time PCR. Nucleic Acids Research 31(17): 105.

21. Dorak MT (2006). Real-Time PCR (Advanced Methods Series). Oxford Taylor \& Francis. Available: (http:/dorakmt.tripod.com/genetics/realtim e.html).

22. Mcomish F, Yap PL, Dow BC, Follett, EAC, Seed C, Keller AJ, Cobain TJ, Krusius T, Kolho E, Naukkarinen R, Lin C, Lai C, Leong S, Medgyesi GA, Hejjas M, Kiyokawa H, Fukada K, Cuypers T \& Saeed AA (1994). A. Geographical Distribution of Hepatitis C Virus Genotypes in Blood Donors: an International Collaborative Survey. Journal of Clinical Microbiology. 884892.

23. Pfaffl MW, Horgan GW \& Dempfle L (2002). Relative expression software tool (REST) for group-wise comparison and statistical analysis of relative expression 
results in Real Time PCR. Nucleic Acids Res 30: e36.

24. Gause WC \& Adamovicz J (1994). The use of the PCR to quantitative gene expression. PCR Meth Appl 3: 123-135.

25. Rys PN \& Persing DH (1993). Preventing false positives: quantitative evaluation of three protocols for inactivation of polymerase chain reaction amplification products. J Clin. Microbiol. 31:23562360.

26. Victor T, Jordaan A, Toit du R \& Van Helden PD (1993). Laboratory experience and guidelines for avoiding false positive polymerase chain reaction results. J Clin Chem Clin Biochem. 31:531-535.

27. Khattak NM, Akhtar S, Mahmud S, Roshan MT (2008). Factors Influencing
Hepatitis C Virus Seroprevalence among Blood Donors in North West Pakistan. Journal of Public Health Policy. 29:207225.

28. Sanaullah K, Sobia A, Sultan A, Shahid NK, Sumaira S, Ijaz A, Muhammad B \& Sami S (2011). Molecular epidemiology of HCV among health care workers of Khyber Pakhtunkhwa.Virology Journal. 8:105.

29. WHO Guidelines Approved by the Guidelines Review Committee (2014). Guidelines for the Screening, Care and Treatment of Persons with Hepatitis C Infection. Geneva: World Health Organization [PMID: 25535634]. 